\title{
Endothelial nitric oxide synthase, angiotensin- converting enzyme and angiotensinogen gene polymorphisms in hypertensive disorders of pregnancy
}

\author{
Pardeep Kumar Aggarwal ${ }^{1}$, Vanita Jain ${ }^{2}$ and Vivekanand Jha ${ }^{1}$
}

We investigated the variations in genes encoding endothelial nitric oxide synthase (NOS3), angiotensin-converting enzyme $(A C E)$ and angiotensinogen $(A G T)$ in hypertensive disorders of pregnancy and the relationship between the polymorphisms and circulating nitric oxide (NO) and ACE levels in pregnant north Indian women. Frequencies of NOS3 G894T, 4b/a and $\mathrm{T}^{-786} \rightarrow \mathrm{C}, A G T \mathrm{T704C}$ and $A C E$ ins/del polymorphisms were studied in 342 subjects: 120 with preeclampsia (PE), 104 with gestational hypertension and 118 normotensive pregnant women. Variations were evaluated by polymerase chain reactionrestriction fragment length polymorphism. NO and ACE levels were determined using ELISA. There was no difference in the distribution of individual NOS3 and ACE polymorphisms in the study groups. Haplotype analysis showed a global difference in the NOS3 haplotype distribution between the PE and non-PE subjects $(P=0.03)$. The presence of $A G T 704 C$ allele was associated with a reduced risk of developing PE (odds ratio: $0.33,95 \% \mathrm{Cl}: 0.19-0.59$ in recessive mode). Circulating total NO and ACE levels were similar in three groups. No relationship was found between circulating NO levels and any of the NOS3 polymorphisms, but the circulating ACE levels were higher in those with DD genotype $(P<0.05)$. In conclusion, there was no association between individual NOS3 and the $A C E$ gene polymorphisms and hypertensive disorders of pregnancy in north Indian women. The presence of minor alleles at all the three sites in NOS3 seemed to increase the risk of PE, and AGT 704C allele was associated with a reduced PE risk. The complexity of interaction between these genetic abnormalities requires further studies.

Hypertension Research (2010) 33, 473-477; doi:10.1038/hr.2010.23; published online 26 February 2010

Keywords: $A C E ; A G T$; gestational hypertension; preeclampsia; NOS3

\section{INTRODUCTION}

Preeclampsia (PE) is a major complication of pregnancy and increases fetal and maternal morbidity and mortality. ${ }^{1} \mathrm{PE}$ usually manifests after the 20th week of gestation and regresses postpartum. The clinical manifestations suggest a perturbation of the balance in vasoactive factors in favor of vasoconstriction.

Though the familial component of PE is well documented, ${ }^{2}$ the precise function of genetic factors remains unclear. Linkage and epidemiologic analyses suggest a polygenic inheritance pattern with strong nongenetic component. ${ }^{3}$

Renin-angiotensin system and endothelial nitric oxide synthase (NOS3) are important regulators of vascular tone and salt and water homeostasis, and contribute to spiral artery remodeling during placentation that reduces uteroplacental resistance typical of normal pregnancy. ${ }^{4,5}$ A function for variations in genes encoding endothelial NOS3, angiotensinogen $(A G T)$ and angiotensin-converting enzyme $(A C E)$ in the genesis of PE has been speculated, but studies in different population groups have yielded conflicting results. We evaluated three functionally important polymorphisms in the NOS3 gene, namely G894T in exon 7, 4b/a in intron 4 and $\mathrm{T}^{-786} \rightarrow \mathrm{C}$; AGT T704C in exon 2 and $A C E$ intron $16 \mathrm{ins} / \mathrm{del}$ (I/D) polymorphism in a cohort of preeclamptic, gestational hypertensive $(\mathrm{GH})$ and normotensive pregnant women. We also measured the circulating total nitric oxide (NO) and ACE levels in the three groups and evaluated their relationship with genotypes.

\section{METHODS}

Subjects were recruited from the Antenatal Clinic and Wards of the Department of Obstetrics and Gynecology, Postgraduate Institute of Medical Education and Research, Chandigarh, a large tertiary care hospital in north India.

$\mathrm{PE}$ was defined as new onset of elevated blood pressure $>140 / 90 \mathrm{~mm} \mathrm{Hg}$ using a standard mercury sphygmomanometer along with proteinuria $\geqslant 2+$ on dipstick on two occasions at least $6 \mathrm{~h}$ apart or $>300 \mathrm{mg}$ per day on two occasions after 20 weeks of gestation in earlier normotensive pregnant women

${ }^{1}$ Department of Nephrology, Postgraduate Institute of Medical Education and Research, Chandigarh, India and ${ }^{2}$ Department of Obstetrics and Gynaecology, Postgraduate Institute of Medical Education and Research, Chandigarh, India

Correspondence: Dr V Jha, Department of Nephrology, Postgraduate Institute of Medical Education and Research, Chandigarh 160012 , India.

E-mail: vjha@pginephro.org

Received 22 October 2009; revised 17 December 2009; accepted 14 January 2010; published online 26 February 2010 
(American Society of Obstetrics and Gynecology Technical Bulletin \# 91, 1986). GH was defined as new onset of elevated blood pressure $>140 / 90$ after 20 weeks of gestation on two occasions at least $6 \mathrm{~h}$ apart in the absence of any proteinuria in earlier normotensive and nonproteinuric pregnant women. Patients were followed up after delivery to document normalization of blood pressure. The normotensive control group had women with uncomplicated gestation and blood pressure $<125 / 85 \mathrm{~mm} \mathrm{Hg}$ and no proteinuria. Subjects were excluded if they had one or more of the following: hypertension before 20 weeks of gestation, diabetes, asthma, heart disease, kidney disease, hematological disorder, autoimmune disease, urinary tract infection, current or past history of smoking, twin/molar pregnancy and eclampsia.

Institute Ethics committee approved the study protocol and all subjects provided informed consent.

After establishing the diagnosis through careful history, full clinical examination and urinalysis, venous blood was collected, plasma/serum separated and stored in sterile cryovials at $-80^{\circ} \mathrm{C}$. Buffy coat was stored at $-20^{\circ} \mathrm{C}$ until DNA isolation.

\section{Polymorphism analysis}

Genomic DNA was extracted from cells in the buffy coat using QIAamp DNA mini kit (Qiagen GmbH, Hinden, Germany) as per manufacturer's instructions. Gene polymorphisms were detected using polymerase chain reaction followed by restriction fragment length polymorphism. Table 1 shows the primer sequences, reaction conditions, restriction enzymes used and fragment sizes for the various reactions. To exclude the possibility of the ACE ID genotypes getting mistyped as DD because of preferential amplification of D allele, all DD were re-amplified using insertion specific primer pairs that gave a $335 \mathrm{bp}$ fragment in the presence of I allele.

\section{Angiotensin-converting enzyme}

Serum ACE levels were quantitated in duplicate by a sandwich enzyme immunoassay using Human ACE Immunoassay kit (R\&D Systems, Minneapolis, MN, USA). The inter- and intra-assay coefficients of variation were 5.90 and $3.76 \%$, respectively.

\section{Total NO}

The plasma total NO levels were quantitated in duplicate using Total NO/ Nitrite/Nitrate Assay kit (R\&D Systems) as per the instructions of the manufacturer. Briefly, the plasma samples were filtered through $10 \mathrm{kDa}$ cutoff filters to eliminate proteins and the filtrate was used to determine total NO levels after conversion of nitrate into nitrite using nitrate reductase. The interand intra-assay coefficients of variation were 3.86 and $1.83 \%$, respectively.

\section{Statistical analysis}

Statistical analysis was performed using SPSS 13 (SPSS, Chicago, IL, USA) and Epi-info. One-factor post hoc ANOVA with Bonferroni corrections was used to compare the means of clinical characteristics. Expected genotype frequencies were determined using the Hardy-Weinberg calculator (http://www.tufts.edu/ $\sim$ mcourt01/Documents/Court\%20lab\%20\%20HW\%20calculator.xls) and analyzed using the appropriate $\chi^{2}$ test. Odds ratios were calculated using Epi-Info software. NOS3 haplotype analysis was performed using SHEsis software. ${ }^{6} \mathrm{NO}$ and ACE levels were compared using Mann-Whitney $U$-test. A $P$-value of $<0.05$ was considered as significant.

\section{RESULTS}

A total of 342 subjects (120 with PE, 104 with GH and 118 normotensive pregnant women) were included in the study. Table 2 shows the demographic details of the enrolled subjects. Mean age of the pregnant women was similar in the three groups, but gestational age of women with PE was lower compared with the normotensive controls. As expected, the mean systolic and diastolic blood pressures were elevated in $\mathrm{PE}$ and GH $(P<0.001)$, and proteinuria was present only in PE group. Table 3 shows the distributions of genotype and allele frequencies for all the polymorphisms in the three groups. The genotype and allele frequency distribution for all the studied polymorphisms were in accordance with Hardy-Weinberg equilibrium. No significant variation was observed in the individual genotype and allele distribution of NOS3 and ACE. AGT 704 CC genotype and C allele frequencies were significantly reduced in $\mathrm{PE}(P=0.0002$ and

Table 1 Polymerase chain reaction (PCR) and restriction fragment length polymorphism (RFLP) conditions

\begin{tabular}{|c|c|c|c|c|c|c|}
\hline $\begin{array}{l}\text { Gene } \\
\text { (accession no.) }\end{array}$ & $\begin{array}{l}\text { Polymorphic } \\
\text { site }\end{array}$ & Primer sequence $\left(5^{\prime}-3^{\prime}\right)$ & $\begin{array}{l}\text { Denaturation, annealing } \\
\text { and extension }\end{array}$ & $\begin{array}{l}\text { Product } \\
\text { size }(b p)\end{array}$ & $\begin{array}{l}\text { Restriction enzyme } \\
\text { (incubation duration) }\end{array}$ & $\begin{array}{l}\text { Genotype and restriction } \\
\text { fragment }(b p) \text { pattern }\end{array}$ \\
\hline \multirow[t]{6}{*}{ ACE (A28005) } & I/D & F:CTGGAGACCACTCCCATCCTTTCT & $95^{\circ} \mathrm{C}$ for $30 \mathrm{~s}$ & $490 / 190$ & & II: 490 \\
\hline & & R:GATGTGGCCATCACATTCGTCAGA & $57^{\circ} \mathrm{C}$ for $30 \mathrm{~s}$ & & & ID: 490 and 190 \\
\hline & & & $72^{\circ} \mathrm{C}$ for $45 \mathrm{~s}$ & & & DD: 190 \\
\hline & I allele & F:TGGGACCACAGCGCCCGCCACTAC & $95^{\circ} \mathrm{C}$ for $30 \mathrm{~s}$ & 335 & & II: 335 \\
\hline & & R:TCGCCAGCCCTCCCATGCCCATAA & $76^{\circ} \mathrm{C}$ for $30 \mathrm{~s}$ & & & DD: no product \\
\hline & & & $72^{\circ} \mathrm{C}$ for $45 \mathrm{~s}$ & & & \\
\hline \multirow[t]{9}{*}{ NOS3 (D26607) } & G894T & F:TCCCTGAGGAGGGCATGAGGCT & $94^{\circ} \mathrm{C}$ for $1.0 \mathrm{~min}$ & 457 & Ban // (5U) $\left(37^{\circ} \mathrm{C}\right.$ for $\left.5 \mathrm{~h}\right)$ & GG: 320 and 157 \\
\hline & & R:TGAGGGTCACACAGGTTCCT & $63^{\circ} \mathrm{C}$ for $1.0 \mathrm{~min}$ & & & GT: 457,320 and 157 \\
\hline & & & $72^{\circ} \mathrm{C}$ for $1.0 \mathrm{~min}$ & & & TT: 457 \\
\hline & $4 b / a$ & F:AGGCCCTATGGTAGTGCCTTT & $94^{\circ} \mathrm{C}$ for $1.0 \mathrm{~min}$ & $420 / 393$ & & 4bb: 420 \\
\hline & & R:TCTCTTAGTGCTGTGGTCAC & $61^{\circ} \mathrm{C}$ for $1.0 \mathrm{~min}$ & & & 4ba: 420 and 393 \\
\hline & & & $72^{\circ} \mathrm{C}$ for $1.0 \mathrm{~min}$ & & & 4aa: 393 \\
\hline & $\mathrm{T}^{-786} \rightarrow \mathrm{C}$ & F:GCATGCACTCTGGCCTGAAGTG & $95^{\circ} \mathrm{C}$ for $45 \mathrm{~s}$ & 222 & Msp $1(5 \mathrm{U})\left(37^{\circ} \mathrm{C}\right.$ for $\left.5 \mathrm{~h}\right)$ & TT: 161 and 61 \\
\hline & & R:CAGGAAGCTGCCTTCCAGTGC & $67^{\circ} \mathrm{C}$ for $45 \mathrm{~s}$ & & & TC: $161,116,61$ and 45 \\
\hline & & & $72^{\circ} \mathrm{C}$ for $1.0 \mathrm{~min}$ & & & CC: 116,61 and 45 \\
\hline \multirow[t]{3}{*}{ AGT (AH002594) } & T704C & F:CAGGGTGCTGTCCACACTGGACCCC & $95^{\circ} \mathrm{C}$ for $1.0 \mathrm{~min}$ & 165 & Tth111 I (5U) $\left(37^{\circ} \mathrm{C}\right.$ for $\left.8 \mathrm{~h}\right)$ & TT: 165 \\
\hline & & R: CCGTTTGTGCAGGGCCTGGCTCTCT & $67^{\circ} \mathrm{C}$ for $45 \mathrm{~s}$ & & & TC: 165,141 and 24 \\
\hline & & & $72^{\circ} \mathrm{C}$ for $1.5 \mathrm{~min}$ & & & CC: 141 and 24 \\
\hline
\end{tabular}

Abbreviations: ACE, angiotensin-converting enzyme; AGT, angiotensinogen; NOS3, nitric oxide synthase. 
Table 2 Demographic characteristics of the study subjects

\begin{tabular}{|c|c|c|c|c|c|}
\hline & $\begin{array}{c}P E \\
(\mathrm{n}=120)\end{array}$ & $\begin{array}{c}G H \\
(n=104)\end{array}$ & $\begin{array}{c}N \\
(\mathrm{n}=118)\end{array}$ & \multicolumn{2}{|c|}{ P-value } \\
\hline Gestational age at delivery (weeks) & $33.2 \pm 2.7$ & $35.3 \pm 2.4$ & $35.9 \pm 2.7$ & $<0.001$ & NS \\
\hline \multicolumn{6}{|l|}{ Blood pressure $(\mathrm{mm} \mathrm{Hg})$} \\
\hline Proteinuria (dipstick) & $3.03 \pm 0.78$ & $\mathrm{Nil}$ & Nil & & \\
\hline
\end{tabular}

Abbreviations: $\mathrm{GH}$, gestational hypertension; $\mathrm{PE}$, preeclampsia; $\mathrm{N}$, normotensive.

Table 3 Distribution of NOS3, ACE and AGT genotypes and alleles

\begin{tabular}{|c|c|c|c|}
\hline Polymorphism & $P E$ & GH & $N$ \\
\hline \multicolumn{4}{|l|}{ NOS3 G894T } \\
\hline GG & $64(53.3)$ & $65(62.5)$ & $70(59.3)$ \\
\hline GT & $46(38.3)$ & 37 (35.6) & $42(35.6)$ \\
\hline $\mathrm{TT}$ & $10(8.3)$ & $2(1.9)$ & $6(5.1)$ \\
\hline Minor allele frequency & 0.28 & 0.20 & 0.23 \\
\hline \multicolumn{4}{|l|}{ NOS3 $4 \mathrm{~b} / \mathrm{a}$} \\
\hline $\mathrm{bb}$ & $83(69.2)$ & $55(52.9)$ & $74(62.7)$ \\
\hline ba & $32(26.7)$ & $42(40.4)$ & $39(33.0)$ \\
\hline aa & $5(4.2)$ & $7(6.7)$ & $5(4.3)$ \\
\hline Minor allele frequency & 0.18 & 0.27 & 0.21 \\
\hline \multicolumn{4}{|l|}{ NOS3 $T^{-786} \rightarrow C$} \\
\hline TT & $80(66.7)$ & $67(64.4)$ & $74(62.7)$ \\
\hline $\mathrm{TC}$ & $35(29.2)$ & $34(32.7)$ & $40(33.9)$ \\
\hline $\mathrm{CC}$ & $5(4.2)$ & $3(2.9)$ & $4(3.4)$ \\
\hline Minor allele frequency & 0.19 & 0.19 & 0.20 \\
\hline \multicolumn{4}{|l|}{$A C E I / D$} \\
\hline II & $38(31.7)$ & $41(39.4)$ & $45(38.1)$ \\
\hline ID & $66(55.0)$ & $45(43.3)$ & $54(45.7)$ \\
\hline DD & $16(13.3)$ & $18(17.3)$ & $19(16.2)$ \\
\hline Minor allele frequency & 0.41 & 0.39 & 0.39 \\
\hline \multicolumn{4}{|l|}{ AGT T704C } \\
\hline $\mathrm{TT}^{*}$ & $7(5.8)$ & $2(1.9)$ & $4(3.3)$ \\
\hline $\mathrm{TC}$ & $55(45.8)$ & $28(26.9)$ & $27(22.8)$ \\
\hline $\mathrm{CC}$ & $58(48.3)$ & $74(71.2)$ & $87(73.9)$ \\
\hline Minor allele frequency** & 0.71 & 0.85 & 0.85 \\
\hline
\end{tabular}

Abbreviations: $A C E$, angiotensin-converting enzyme; $A G T$, angiotensinogen; $\mathrm{GH}$, gestational hypertension; I/D, ins/del; $\mathrm{PE}$, preeclampsia; $\mathrm{N}$, normotensive; NOS3, nitric oxide synthase. hypertension; $1 / D$, ins/del; $P E$, preeclampsia; $N$, normotensive; NOS3, nitric oxide synthe
Numbers in parentheses indicate percentages, ${ }^{*} P=0.0002,{ }^{*} P=0.0004$ (PE vs. N).

0.0004, respectively); and the odds ratio of development of PE in the recessive mode was 0.33 (95\% CI: $0.19-0.59, P=0.00005)$. NOS3 haplotype analysis showed significant $(P=0.003)$ global differences in the frequency distribution. With reference to normal (G894-4bT786) haplotype, the $894 \mathrm{~T}-4 \mathrm{~b}-786 \mathrm{C}$ was associated with increased PE risk $(P=0.03)$, whereas $\mathrm{G} 894-4 \mathrm{~b}-786 \mathrm{C}$ and $894 \mathrm{~T}-4 \mathrm{a}-\mathrm{T} 786$ haplotypes were protective $(P=0.004$ and 0.04$)$ (Table 4$)$.

\section{Correlation of ACE and NO levels with genotype}

Circulating total NO levels $\left(\mu \mathrm{moll}^{-1}\right)$ were $28.7 \pm 11.9$ in the normotensive, $29.9 \pm 10$ in the $\mathrm{GH}$ and $30.8 \pm 17$ in the $\mathrm{PE}$ group $(P>0.05)$. Similarly, the ACE levels $\left(\mathrm{ng} \mathrm{ml}^{-1}\right)$ were also not different between the three study groups $(141.3 \pm 46.3$ in normotensive, $130.4 \pm 37.9$ in GH and $149.7 \pm 50.3$ in PE). None of the NOS3 polymorphisms correlated with total NO levels (Table 5). However, compared with II and ID, ACE levels were higher in the subjects with DD genotype (Figure 1).

\section{DISCUSSION}

The molecules that we investigated are distinguished by their common property of being important players in influencing endothelial cell function and vasomotor tone. Through their actions, they determine whether blood vessels are in a state of vasoconstriction or vasodilatation, systemic blood pressure levels and fluid distribution between different body compartments. Perturbation of endothelial function impacts coagulation pathway. Angiotensin pathway also determines salt and water homeostasis, both directly and through its influence on aldosterone levels. In combination, these are important determinants of the PE phenotype.

This study is the first one to simultaneously examine the distribution of several functionally important polymorphisms (NOS3 G894T, $4 \mathrm{~b} / \mathrm{a}$ and $\mathrm{T}^{-786} \rightarrow \mathrm{C}, A G T$ T704C and $A C E \mathrm{I} / \mathrm{D}$ ), and attempt a correlation between these polymorphisms and circulating total NO and ACE in normotensive and hypertensive pregnancies. In addition, this is the first study to report the NOS3 and AGT polymorphisms in the Indian population. Our population sample was a homogeneous group of north Indian women.

Compared with normotensive pregnancies, we failed to find any difference in the individual frequency of any of the studied NOS 3 and $A C E$ polymorphisms in those with PE or GH. Likewise, the circulating total NO as well as ACE levels were similar among the three study groups. However, our data does suggest that subjects that carry the minor alleles at all three loci in the NOS3 gene have an increased risk of developing PE.

Of the three functionally significant NOS3 polymorphisms, G894T has been studied most frequently, but the results are inconsistent. Studies in Finnish, ${ }^{7}$ North American, ${ }^{8}$ Korean ${ }^{9}$ and British ${ }^{10}$ populations did not show any association between this single-nucleotide polymorphism and occurrence of $\mathrm{PE}$. In contrast, the frequency of $\mathrm{T}$ allele was higher in PE in the Japanese. ${ }^{11}$ A recent meta-analysis found 
Table 4 NOS3 haplotypes and preeclampsia risk

\begin{tabular}{|c|c|c|c|c|c|c|}
\hline G894T & $4 b / a$ & $T^{-786} \rightarrow C$ & Frequency in $P E$ & Frequency in controls & OR $(95 \% \mathrm{Cl})$ & P-value \\
\hline G & $4 a$ & C & 0.084 & 0.059 & $1.43(0.67-3.01)$ & 0.34 \\
\hline G & $4 a$ & $\mathrm{~T}$ & 0.071 & 0.101 & $0.69(0.33-1.29)$ & 0.22 \\
\hline G & $4 b$ & $\mathrm{~T}$ & 0.543 & 0.523 & $1.03(0.70-1.50)$ & 0.89 \\
\hline $\mathrm{T}$ & $4 a$ & $\mathrm{~T}$ & 0.018 & 0.053 & $0.32(0.11-1.00)$ & 0.04 \\
\hline $\mathrm{T}$ & $4 b$ & C & 0.075 & 0.028 & $2.73(1.04-7.19)$ & 0.03 \\
\hline
\end{tabular}

Abbreviations: $\mathrm{Cl}$, confidence interval; NOS3, nitric oxide synthase; OR, odds ratio; $\mathrm{PE}$, preeclampsia. Global $P$-value $=0.03$.

Frequency $<0.03$ in both control and cases has been dropped.

Table 5 NOS3 G894T, 4b/a and $\mathrm{T}^{-786} \rightarrow \mathrm{C}$ genotypes and plasma total NO levels $\left(\mu \mathrm{mol} \mathrm{I}^{-1}\right)$

\begin{tabular}{lllll}
\hline Polymorphic site & Genotype (n) & Mean \pm s.d. & Median & Interquartile range \\
\hline G894T & TT (17) & $25.8 \pm 8.32$ & 25.52 & $18.9-31.1$ \\
& GT (119) & $30.9 \pm 12.8$ & 29.2 & $19.5-39.3$ \\
& GG (180) & $29.5 \pm 14.4$ & 27.7 & $20.1-34.5$ \\
4b/a & & & & \\
& aa (17) & $26.9 \pm 13.4$ & 24.42 & $16.1-30.1$ \\
& ba (112) & $29.9 \pm 16.1$ & 27.8 & $20.5-34.2$ \\
T-786 $\rightarrow$ C & bb (195) & $30.1 \pm 11.9$ & 28.5 & $19.9-38.2$ \\
& CC (11) & $24.1 \pm 15.4$ & 17.5 & $12.8-38.6$ \\
& TC (103) & $31.8 \pm 16.2$ & 29.3 & $20.8-36.5$ \\
& TT (210) & $29.2 \pm 11.7$ & 27.7 & $19.9-35.5$ \\
\hline
\end{tabular}

Abbreviations: $n$, number of subjects; NO, nitric oxide; NOS3, nitric oxide synthase.

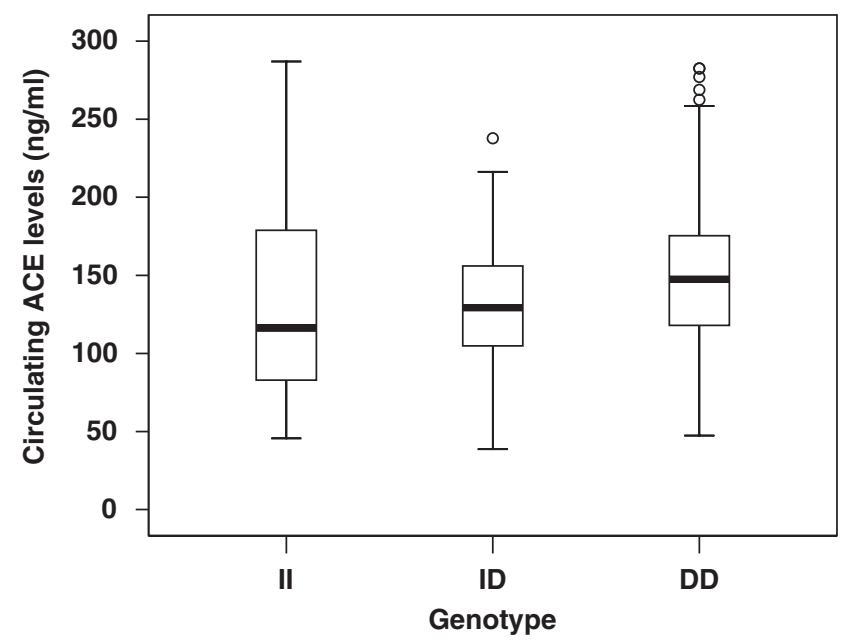

Figure 1 Serum ACE levels in DD, ID and II genotype of ACE gene. The lower and upper bars represent the 10th and 90th percentiles, respectively, and the interquartile range is indicated by the box, the median value being the horizontal line in the box. Significant increase in DD compared with ID and II genotype $(P<0.05)$.

the cumulative odds ratio of 1.24 with $\mathrm{T}$ allele, but the confidence intervals crossed 1, making it nonsignificant. ${ }^{12}$ It can, therefore, be concluded that the association between G894T polymorphism and PE is weak.
Not many studies have examined the association between PE and the other two NOS3 polymorphisms. We did not find an association between the $4 \mathrm{a} / \mathrm{b}$ or $\mathrm{T}^{-786} \rightarrow \mathrm{C}$ polymorphism and $\mathrm{PE}$ or $\mathrm{GH}$ in either modes of inheritance. Some studies have reported an association between $4 \mathrm{~b} / \mathrm{a}$ polymorphism and $\mathrm{PE}^{13}$ and higher blood pressure at an earlier gestational age in the presence of 4aa genotype. ${ }^{14}$ SeremakMrozikiewicz et al. ${ }^{15}$ reported a weak correlation between $-786 \mathrm{C}$ alleles and PE susceptibility in Polish population. Others, however, have found no association between this polymorphism and PE. ${ }^{16}$

Several studies have measured circulating NO levels in PE and found them to be decreased, ${ }^{17}$ increased ${ }^{5,18}$ or unchanged. ${ }^{19}$ We did not find any significant differences in the total circulating NO levels in any of the groups. However, this endothelium-derived molecule has a short half-life and largely acts in an autocrine or paracrine manner, hence circulating levels may not truly reflect the local NO concentration and/or activity. NOS3 genotype affects circulating total NO levels, ${ }^{20}$ but we did not find significant differences in NO levels between the genotypes of all the three studied polymorphisms that is G894T, $4 \mathrm{~b} / \mathrm{a}$ and $\mathrm{T}^{-786} \rightarrow \mathrm{C}$ (Table 5). Haplotype analysis suggests a more complex relationship between these variations and PE risk. The presence of minor alleles at all three sites simultaneously predicted an increased risk, a finding that needs to be studied further.

In contrast to several studies, we found a significant underrepresentation of AGT 704C allele in subjects with PE. In our control population, the frequency of this allele was 0.8 , compared with 0.4 in European Caucasians, ${ }^{21} 0.9$ in Black Africans, ${ }^{22} 0.8$ in Japanese ${ }^{21}$ and 0.7 in Hispanics. ${ }^{14}$ Several studies have documented a higher frequency of the $704 \mathrm{C}$ variant in women with PE. ${ }^{12,21,23}$ Others, however, did not find a difference in the frequency of the two alleles. ${ }^{24-26}$ Our findings are similar to those of Hopkins et al. ${ }^{27}$ who showed a higher frequency of $\mathrm{T}$ allele in Hispanic women with PE. A meta-analysis involving 17 studies concluded that $\mathrm{C}$ allele homozygotes had a 1.62 times higher risk of developing $\mathrm{PE}^{28}$ In our population, the CC genotype and $\mathrm{C}$ allele afforded protection against $\mathrm{PE}$. The significance of this finding along with its relation to the circulating angiotensin-II levels needs to be confirmed in larger cohorts.

Whether or not there is an association between ACE intron $16 \mathrm{I} / \mathrm{D}$ polymorphism and PE is not fully settled. Individuals with DD genotype have ACE activity about twice that of II subjects. ${ }^{29}$ It has been suggested that the DD genotype could predispose to the development of PE. ${ }^{30,31}$ A recent study reported an association between the I/D polymorphism and mild, but not severe PE. ${ }^{32}$ We did confirm the high ACE levels in those with the D allele, but failed to find any difference in the distribution of ACE II, DD and ID genotypes between the three groups. A meta-analysis of 11 studies involving $1121 \mathrm{PE}$ and 1361 control subjects calculated the odds ratio of developing PE at 
1.51 under the recessive model of inheritance. ${ }^{12}$ This was, however, driven largely by two studies, one from Italy ${ }^{33}$ and the other from Korea. $^{31}$ Single population studies, however, have failed to show association. ${ }^{12,22,34}$ Studies that evaluated ACE level in PE and normotensive pregnant women also could not find a difference. ${ }^{30}$

To conclude, we did not find any association between individual polymorphisms in the NOS3 (Glu298Asp in exon 7, 4b/a in intron 4 and $\mathrm{T}^{-786} \rightarrow \mathrm{C}$ ) and the $A C E$ (intron $16 \mathrm{I} / \mathrm{D}$ ) genes and hypertensive disorders of pregnancy. Subjects carrying minor alleles at all the three sites in NOS3 seem to have an increased risk of developing PE. The presence of $A G T$ 704C allele was associated with a reduced PE risk. These findings could be population specific. The complexity of interaction between these genetic abnormalities requires further studies.

\section{CONFLICT OF INTEREST}

The authors declare no conflict of interest.

\section{ACKNOWLEDGEMENTS}

This work was supported by a grant from the Department of Biotechnology, Ministry of Science \& Technology, Government of India to VJ. PKA was supported by a fellowship by the Indian Council of Medical Research.

1 de Swiet M. Maternal mortality: confidential enquiries into maternal deaths in the United Kingdom. Am J Obstet Gynecol 2000; 182: 760-766

2 Esplin MS, Fausett MB, Fraser A, Kerber R, Mineau G, Carrillo J, Varner MW. Paternal and maternal components of the predisposition to preeclampsia. N Engl J Med 2001; 344: 867-872.

3 Arngrimsson R, Sigurardottir S, Frigge ML, Bjarnadottir RI, Jonsson T, Stefansson H, Baldursdottir A, Einarsdottir AS, Palsson B, Snorradottir S, Lachmeijer AM, Nicolae D, Kong A, Bragason BT, Gulcher JR, Geirsson RT, Stefansson K. A genome-wide scan reveals a maternal susceptibility locus for pre-eclampsia on chromosome $2 \mathrm{p} 13$. Hum Mol Genet 1999; 8: 1799-1805.

4 Morgan T, Craven C, Ward K. Human spiral artery renin-angiotensin system. Hypertension 1998; 32: 683-687.

5 Norris LA, Higgins JR, Darling MR, Walshe JJ, Bonnar J. Nitric oxide in the uteroplacental, fetoplacental, and peripheral circulations in preeclampsia. Obstet Gynecol 1999. 93: 958-963.

6 Shi YY, He L. SHEsis, a powerful software platform for analyses of linkage disequilibrium, haplotype construction, and genetic association at polymorphism loci. Cell Res 2005; 15: 97-98.

7 Hakli T, Romppanen EL, Hiltunen M, Helisalmi S, Punnonen K, Heinonen S. Endothelial nitric oxide synthase polymorphism in preeclampsia. J Soc Gynecol Invest 2003; 10: $154-157$.

8 Landau R, Xie HG, Dishy V, Wood AJ, Stein CM, Smiley RM. No association of the Asp298 variant of the endothelial nitric oxide synthase gene with preeclampsia. Am J Hypertens 2004; 17: 391-394.

9 Kim YJ, Park BH, Park H, Jung SC, Pang MG, Ryu HM, Lee KS, Eom SM, Park HY. No association of the genetic polymorphisms of endothelial nitric oxide synthase, dimethylarginine dimethylaminohydrolase, and vascular endothelial growth factor with preeclampsia in Korean populations. Twin Res Hum Genet 2008; 11: 77-83.

$10 \mathrm{Yu}$ CK, Casas JP, Savvidou MD, Sahemey MK, Nicolaides KH, Hingorani AD. Endothelial nitric oxide synthase gene polymorphism (Glu298Asp) and development of pre-eclampsia: a case-control study and a meta-analysis. BMC Pregnancy Childbirth 2006; $6: 7$.

11 Yoshimura T, Yoshimura M, Tabata A, Shimasaki Y, Nakayama M, Miyamoto Y, Saito Y, Nakao K, Yasue H, Okamura H. Association of the missense Glu298Asp variant of the endothelial nitric oxide synthase gene with severe preeclampsia. J Soc Gynecol Invest 2000; 7: 238-241.

12 Medica I, Kastrin A, Peterlin B. Genetic polymorphisms in vasoactive genes and preeclampsia: a meta-analysis. Eur J Obstet Gynecol Reprod Biol 2007; 131: $115-126$
13 Tempfer CB, Dorman K, Deter RL, O'Brien WE, Gregg AR. An endothelial nitric oxide synthase gene polymorphism is associated with preeclampsia. Hypertens Pregnancy 2001; 20: 107-118.

14 Bashford MT, Hefler LA, Vertrees TW, Roa BB, Gregg AR. Angiotensinogen and endothelial nitric oxide synthase gene polymorphisms among Hispanic patients with preeclampsia. Am J Obstet Gynecol 2001; 184: 1345-1350; discussion 1350-1351.

15 Seremak-Mrozikiewicz A, Drews K, Mrozikiewicz PM. The -786T/C polymorphism of the endothelial nitric oxide synthase gene in preeclampsia. Eur J Obstet Gynecol Reprod Biol 2008; 138: 118-119.

16 Hocher B, Chen YP, Hugle S, Repey J, Krause K, Slowinski T, Godes M, Schaeffeler E, Guthmann F, Wauer R, Halle H, Gossing G, Pfab T. Impact of maternal endothelial nitric oxide synthase gene polymorphisms on blood pressure, protein excretion and fetal outcome in pregnancy. J Hum Hypertens 2008; 22: 641-647.

17 Lopez-Jaramillo P. Prevention of preeclampsia with calcium supplementation and its relation with the L-arginine:nitric oxide pathway. Braz J Med Biol Res 1996; 29: 731-741.

18 Yoneyama Y, Suzuki S, Sawa R, Miura A, Doi D, Otsubo Y, Araki T. Plasma nitric oxide levels and the expression of P-selectin on platelets in preeclampsia. Am J Obstet Gynecol 2002; 187: 676-680.

19 Silver RK, Kupferminc MJ, Russell TL, Adler L, Mullen TA, Caplan MS. Evaluation of nitric oxide as a mediator of severe preeclampsia. Am J Obstet Gynecol 1996; 175: 1013-1017

20 Tsukada T, Yokoyama K, Arai T, Takemoto F, Hara S, Yamada A, Kawaguchi Y, Hosoya T, Igari J. Evidence of association of the ecNOS gene polymorphism with plasma NO metabolite levels in humans. Biochem Biophys Res Commun 1998; 245: 190-193.

21 Ward K, Hata A, Jeunemaitre X, Helin C, Nelson L, Namikawa C, Farrington PF, Ogasawara M, Suzumori K, Tomoda S. A molecular variant of angiotensinogen associated with preeclampsia. Nat Genet 1993; 4: 59-61.

22 Roberts CB, Rom L, Moodley J, Pegoraro RJ. Hypertension-related gene polymorphisms in pre-eclampsia, eclampsia and gestational hypertension in Black South African women. J Hypertens 2004; 22: 945-948.

23 Zafarmand MH, Franx A, Sabour S, van der Schouw YT, Grobbee DE, de Leeuw PW, Bots ML. The M235T variant of the angiotensinogen gene is related to development of self-reported hypertension during pregnancy: the Prospect-EPIC cohort study. Hypertens Res 2008; 31: 1299-1305.

24 Suzuki Y, Tanemura M, Murakami I, Suzumori K. Is angiotensinogen gene polymorphism associated with hypertension in pregnancy? Hypertens Pregnancy 1999; 18 : 261-271.

25 Knyrim E, Muetze S, Eggermann T, Rudnik-Schoeneborn S, Lindt R, Ortlepp JR, Rath W, Zerres K. Genetic analysis of the angiotensinogen gene in pre-eclampsia: study of german women and review of the literature. Gynecol Obstet Invest 2008; 66 : 203-208.

26 Jenkins LD, Powers RW, Cooper M, Gallaher MJ, Markovic N, Ferrell R, Ness RB, Roberts JM. Preeclampsia risk and angiotensinogen polymorphisms M235T and AGT -217 in African American and Caucasian women. Reprod Sci 2008; 15: 696-701.

27 Hopkins FW, MacKay AP, Koonin LM, Berg CJ, Irwin M, Atrash HK. Pregnancyrelated mortality in Hispanic women in the United States. Obstet Gynecol 1999; 94: 747-752.

28 Zafarmand MH, Nijdam ME, Franx A, Grobbee DE, Bots ML. The angiotensinogen gene M235T polymorphism and development of preeclampsia/eclampsia: a meta-analysis and meta-regression of observational studies. J Hypertens 2008; 26: $1726-1734$

29 Tiret L, Rigat B, Visvikis S, Breda C, Corvol P, Cambien F, Soubrier F. Evidence, from combined segregation and linkage analysis, that a variant of the angiotensin Iconverting enzyme (ACE) gene controls plasma ACE levels. Am J Hum Genet 1992; 51: 197-205.

30 Gurdol F, Isbilen E, Yilmaz H, Isbir T, Dirican A. The association between preeclampsia and angiotensin-converting enzyme insertion/deletion polymorphism. Clin Chim Acta 2004; 341: 127-131.

31 Choi H, Kang JY, Yoon HS, Han SS, Whang CS, Moon IG, Shin HH, Park JB. Association of angiotensin-converting enzyme and angiotensinogen gene polymorphisms with preeclampsia. J Korean Med Sci 2004; 19: 253-257.

32 Mando C, Antonazzo P, Tabano S, Zanutto S, Pileri P, Somigliana E, Colleoni F, Martinelli A, Zolin A, Benedetto C, Marozio L, Neri I, Facchinetti F, Miozzo M, Cetin I. Angiotensin-converting enzyme and adducin-1 polymorphisms in women with preeclampsia and gestational hypertension. Reprod Sci 2009; 16: 819-826.

33 Mello G, Parretti E, Gensini F, Sticchi E, Mecacci F, Scarselli G, Genuardi M, Abbate R, Fatini C. Maternal-fetal flow, negative events, and preeclampsia: role of ACE I/D polymorphism. Hypertension 2003; 41: 932-937.

34 Galao AO, de Souza LH, da Costa BE, Scheibe RM, Poli de Figueiredo CE. Angiotensinconverting enzyme gene polymorphism in preeclampsia and normal pregnancy. Am J Obstet Gynecol 2004; 191: 821-824. 